\title{
ERRATA
}

\section{ERRATUM TO: DISTORTION OF THE TETRAHEDRAL COORDINATION OF Fe(III) IONS STABILIZED IN ZSM-5 ZEOLITE FRAMEWORK}

\author{
S. E. Malykhin, V. F. Anufrienko, \\ E. J. M. Hensen, E. V. Kuznetsova, T. V. Larina,
} and G. M. Zhidomirov

Journal of Structural Chemistry, Vol. 48, No. 5, pp. 855-861, September, 2007

DOI: $10.1134 / \mathrm{S} 0022476615040344$

In the original publication the name of one of the authors had been misspelled.

The correct name is E. J. M. Hensen.

The online version of the original article can be found under doi: 10.1007/s10947-007-0127-4. 